\title{
Th-1 Directing Immunostimulatory Effect of Calcined Jade Having Naturally Formed Nanoparticles in Swiss Albino Mice
}

\author{
Asif Elahi ${ }^{1}$ and Farah Khan ${ }^{2 *}$ \\ ${ }^{1}$ Department of Medicine, University of California, USA \\ ${ }^{2}$ Department of Biochemistry, Hamdard University, India
}

Submission: June 12, 2017; Published: August 08, 2017

*Corresponding author: Farah Khan, Department of Biochemistry, Faculty of Science, Jamia Hamdard, Hamdard Nagar, New Delhi-110 062, Ext. 5514, India, Tel: +91-011-26059888; Email: fkhan@jamiahamdard.ac.in

\begin{abstract}
In present study, we evaluated the modulating potential of Calcined Jade (CJ) on cell mediated immunity in Swiss albino mice. CJ is a metasilicate of Calcium and magnesium prescribed along with other herbal formulations in folk medicine for various purposes. CJ was administered orally to the animals at a dose of 50, 75, 100 and $200 \mu \mathrm{g} / \mathrm{kg}$ body wt. for 10 days; modulation of the acquired immune responses was studiedin mice. In CJ treated animals, cell mediated immune response was observed by estimation of significant increase $(\mathrm{p}<0.01)$ in Delayed type hypersensitivity (DTH) response, Th- 1 cytokines namely IL-2/IFN- $\gamma$ and TNF- $\alpha$ in spleenocytes. We also evaluated the effect of CJ on macrophage surface antigen markers (CD-80/86) and found increased expression of CD-80. We report stimulating effect of CJ on Th-1 type of immune responses which may partly be due to the formation of nano particles during calcination process and further experiments using isolated nano particles may further validate the role of nano particles.
\end{abstract}

Keywords: Calcined Jade; Immunomodulation; TLR-2; CD-80; Th1 response

Abbreviations: FBS: Fetal Bovine Serum; CFA: Complete Freund's Adjuvant; Incomplete Freund's adjunant (IFA) ovalbumin (OVA), 3-(4,5-dimethylthiazol-2-yl)-2,5-diphenyl-tetrazolium bromide (MTT)- Concanavalin A (ConA) Fluorescein isothiocyanate (FITC) Ammonium chloride ( $\mathrm{NH} 4 \mathrm{Cl}$ ), dimethyl sulfoxide (DMSO)

\section{Introduction}

Metal ions are essential components of biological systems; nevertheless, even essential elements may have toxic or carcinogenic properties when they are accumulated in a higher concentration and elicit their effects by altering various biological processes in the system [1]. Accumulated toxicity data on the hazardous effects of heavy metals has made health scientists' sceptic for the use of heavy metals as therapeutics. As a result, renewed interest in the beneficial effects of metals and minerals is often viewed with uncertainty. However, available literature from all the ancient civilizations indicates that man has used metals in disease treatment since long ago. Ayurveda, Unani and other Indian systems of medicine used metals and their use is also thoroughly described in Chinese and Egyptian civilizations in 2500 B.C. [2]. Even the use of gold in medicine was also mentioned by Roman physicians. In addition to the use of gold, other metals have also been extensively described in Indian and other ancient systems of medicine which includes silver, arsenic, cop per, iron, lead, mercury, and zinc. As far as Ayurveda, Unani and other Indian systems of medicine are concerned, metals have been used mainly in the form of ash. The process of making of metal into ash is known as calcination.

The traditional technique of calcination is an elaborate process wherein metals, metallic oxides, non metals and their compounds or mineral and animal origin drugs are oxidized through action of heat and yields a product in the form of fine powder that is believed to have enhanced efficiency and exerts curative role promptly and effectively [3]. The presence of novel biological nano particles formed through the elaborate process of calcination of metallic and mineral compounds in traditional pharmaceutics has been hypothesized since long time and is now receiving a new thrust.

The importance of nano particles as therapeutics lies in their bioavailability, rapid and targeted action. However only a 
small number of studies have been reported so far that clearly establish traditional mineral drugs exhibiting promising effect. Due to the lack of detailed information and absence of scientific methodologies on the use of heavy metals present in traditional mineral drugs, this field has been significantly ignored by the researchers. Additionally, the scientific proofs of the presence of nano particles in traditional pharmaceutics were also missing [4-7].

In the present study, we report the immumo stimulating potential of calcined form of Jade, which is a metamorphic rock that is composed of two different silicates of minerals, jadeite and nephrite. Jadeite is a meta-silicate of sodium and aluminum associated in its natural state with small quantity of iron, calcium, magnesium. It belongs to pyroxine group of mineral and it is commonly granular, and less of fibrous. Nephrite is a silicate of calcium and magnesium associated in its natural states with small quantities of iron which gives it varying shades of color from white (Termite) to dark green (AC tenolite) [8].

Jade in calcined form is frequently used in prescriptions of traditional systems of medicine prescribed as rejuvenator or vitalizer which strengthens the vital organs of the body. It is useful in palpitation, dysentery, burning micturation hemorrhage. In combination with other medicines, Jade is prescribed in treating tuberculosis, jaundice, dyspepsia and urinary complaints [8]. We report the presence of nano particles in the calcined form of Jade in the present study that might be responsible for its immuno modulating potential

\section{Materials and Methods}

\section{Chemicals and Reagents}

The CJ powder was a kind gift provided by late Professor M. S. Y. Khan, Jamia Hamdard, New Delhi, India. Fetal bovine serum (FBS), RPMI 1640 medium, Complete Freund's adjuvant (CFA), Incomplete Freund's adjunant (IFA) ovalbumin (OVA), penicillin-streptomycin, 3-(4,5-dimethylthiazol-2-yl)-2,5-diphenyl-tetrazolium bromide (MTT) and Concanavalin A (Con A) were purchased from Sigma (St. Louis, MO). Fluorescein isothiocyanate (FITC)-labeled anti mouse-CD80, phycoerythrin (PE)-labeled anti-CD86 antibodies were purchased from BD Biosciences (San Diego, CA, USA). Ammonium chloride ( $\mathrm{NH} 4 \mathrm{Cl}$ ), dimethyl sulfoxide (DMSO) and trypan blue was purchased from S.D. Fine Chemicals Ltd. (Mumbai, India). Goat red blood cells (g RBCs) were collected from local slaughter house.

\section{Animals}

The study was approved by Institute's animal ethical committee and conformed to national guidelines on the care and use of laboratory animals. Swiss Albino mice, male, 6-8 week sold, weighing 20-25g was used for the study. The animals were maintained at $25 \pm 2{ }^{\circ} \mathrm{C}$, photoperiod of $12 \mathrm{hrs}$, in the Institute's animal house and fed with commercial pellet diet and water ad libitum.

\section{Treatment}

Animals were divided into five groups comprised of a minimum of 5 mice. CJ was suspended in deionized water at a dose of 50, 75, 100 and $200 \mu \mathrm{g} / \mathrm{kg}$ body wt. with $0.5 \%$ Sodium Carboxy Methyl Cellulose [Na CMC] and administered orally for 10 days (Group II-V). Animals in control group received Na CMC for the same periods and concentration (Group I).Day 11 (24 h after final dosing) was considered as Day 0 in all subsequent protocols outlined below.

\section{Flow Cytometric Analysis of Macrophage Surface An- tigen Markers}

On Day 0, Surface antigen markers (CD-80 and CD-86) were detected by flow cytometry in the peritoneal macrophages harvested by administering $10 \mathrm{ml}$ of ice cold PBS in the peritoneal cavity of each mouse. Cells were washed thrice with stain buffer containing FBS (BD Bioscience) and centrifuged at $300 \mathrm{x} g$ at $4{ }^{\circ} \mathrm{C}$ for $5 \mathrm{~min}$. Cells were re-suspended in cold stain buffer containing FBS to a final concentration of 106 cells $/ \mathrm{ml}$. The cell suspension was incubated with diluted (1:1000) fluorescent antibodies (stained withFITC-anti-CD-80 and PE-anti-CD-86) for $30 \mathrm{~min}$ on ice in dark chamber. Cells were washed twice with stain buffer containing FBS to remove unbound antibodies. Cell pellet was re-suspended in $0.5 \mathrm{ml}$ stain buffer containing FBS and above mentioned surface antigen markers were analyzed in BD LSR II flow cytometer (BD Biosciences) [9].

\section{Analysis of Cell Mediated Immunity DTH Response}

DTH response was determined as described by Bashir et al. [10], with slight modifications [10]. Briefly, On Day 0, mice were immunized with $1 \times 10^{9}$ goat RBCs (g RBC) subcutaneously. On day $5,1 \times 10^{8} \mathrm{gRBC}$ suspended in $100 \mu \mathrm{l}$ PBS were injected into the left hind footpad of each mouse. $100 \mu \mathrm{l}$ of PBS injected into the right footpad served as control. The footpad thickness was measured with a dial caliper after $24 \mathrm{~h}$ and the results were expressed as the mean percentage increase in footpad thickness. The mean percentage increase was calculated according to the following formula: [(Thickness of the left footpad challenged with goat RBCs) - (Thickness of the right footpad injected with PBS)] x 100 / (Thickness of right footpad injected with PBS).

\section{Lymphocyte Proliferation Assay}

For analysis of effect on lymphocyte proliferation, mice were immunized intramuscularly on Day 0 with $50 \mu$ g OVA emulsified in CFA. Booster dose of $25 \mu \mathrm{g}$ OVA emulsified in IFA was injected on Day 8 and animals were euthanized by cervical dislocation on Day 12. Spleen cells were collected and single cell suspension was prepared by teasing spleen. RBCs present in spleen single cell suspension were lysed using $0.9 \% \mathrm{NH}_{4} \mathrm{Cl}$ and were cultured in RPMI-1640 media containing 10\% fetal calf serum (Sigma, USA). Cell viability was checked using trypan blue dye exclusion test. Cells were plated in 96 well tissue culture plate ( Tarson , 
India) at a density of $2 \times 10^{5}$ cells $/ 100 \mu \mathrm{l} /$ well and then stimulated with the optimal concentration of OVA ( $5 \mu \mathrm{g} / \mathrm{ml}$ ) (Sigma, USA), positive control (Concanavalin A, $2 \mu \mathrm{g} / \mathrm{ml}$ ) (Sigma, USA) and negative control (plain media). These cells were cultured for 72 hours in the incubator at $37^{\circ} \mathrm{C}$ containing $5 \% \mathrm{CO}_{2}$.

Media was aspired form each well and stored at $-70^{\circ} \mathrm{C}$ for cytokines analysis. Then, $20 \mu \mathrm{l}$ of MTT (Sigma, USA) stock solution ( $5 \mathrm{mg} / \mathrm{ml}$ ) was added to each well followed by incubation for $1 \mathrm{~h}$. The medium was aspirated and the formazan crystals (MTT formazan) were solubilized by adding $200 \mu \mathrm{l}$ of DMSO. Plates were incubated in dark at room temperature for $2 \mathrm{~h}$ and absorbance was measured at $570 \mathrm{~nm}$ by a microplate ELISA reader (ECIL, Hyderabad) [11].

\section{Cytokine Analysis}

The level of cytokines like IL-2, IFN- $\gamma$, IL-4, IL-10, IL1 $\beta$ and TNF- $\alpha$ was measured in culture supernatants of all treatment groups collected during lymphocyte cell proliferation assay. The culture supernatants were thawed at $37^{\circ} \mathrm{C}$ and centrifuged at $5000 \mathrm{rpm}$ for $15 \mathrm{~min}$. Supernatants were filtered through $0.22 \mu$ membranes and assayed for cytokine using ELISA development system kits (e- Bioscience USA) as per manufacturer's instructions.

\section{Statistical Analysis}

The statistical analysis of all the treatment groups and the significance of differences between treated and control groups was determined using Graph Padprism software (Dunnet student's t-test) and $p<0.05$ was chosen as the level of significance.

\section{Results}

\section{Effect of CJ on macrophage co-stimulatory molecules CD-80/86}

Expression of co-stimulatory molecule CD-80 cells was elevated at all dose levels, that is 50 (7.3\%), 75 (25.6\%), 100 $(26.8 \%)$ and $200(6.6 \%) \mu \mathrm{g} / \mathrm{kg}$ body weight as compared with controls $(0.1 \%)$ (Figure 1$)$. The expression of CD-86 in macrophages was decreased at all doses. Maximum increase in the expression of CD-80 was observed at $100 \mu \mathrm{g} / \mathrm{kg}$ body weight and maximum decrease in CD-86 was observed at same dose. Double positive cells were also found to be decreased as compared to control.

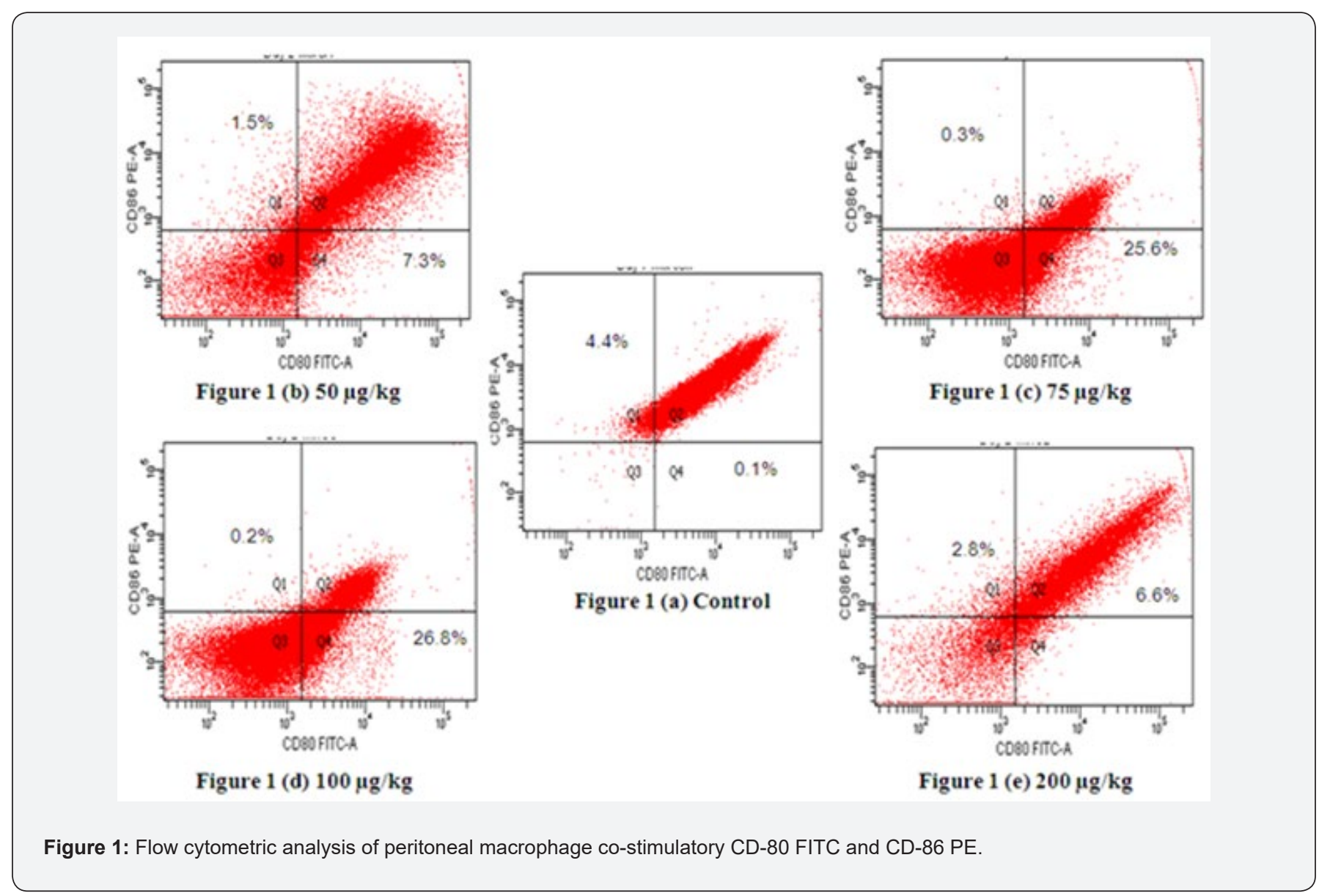

Staining of peritoneal macrophages was done with surface markers CD-80 (FITC-conjugated monoclonal antibody) and CD-86 (PE-conju-

gated monoclonal antibody). 1(a) Control;1(b) $50 \mu \mathrm{g} / \mathrm{kg}$ dose;1(c) 75 $\mu \mathrm{g} / \mathrm{kg}$ dose $1(\mathrm{~d}) 100 \mu \mathrm{g} / \mathrm{kg}$ dose $1(\mathrm{e}) 200 \mu \mathrm{g} / \mathrm{kg}$ dose. 


\section{Effect of CJ on cell-mediated immunity (CMI)}

Effect of CJ on Delayed-type Hyper-Sensitivity (DTH) Response

Delayed-type hyper-sensitivity (DTH) response was found to be significantly increased at a dose of $75(p<0.05), 100(p<0.01)$ and $200 ` \mu \mathrm{g} / \mathrm{kg}$ body weight (Table 1 ). The peak DTH response was observed at $100 \mu \mathrm{g} / \mathrm{kg}$ body weight (Table 1 ). The enhancement footpad thickness upon challenging the mice with gRBCs in $\mathrm{CJ}$ treated mice suggested enhanced cell mediated immune response.

Table 1: Effect of CJ on cell-mediated immunity.

\begin{tabular}{|c|c|c|c|c|c|}
\hline Immune Responses & Group I: Control & 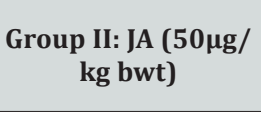 & 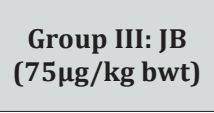 & $\begin{array}{l}\text { Group IV: JC } \\
(100 \mu \mathrm{g} / \mathrm{kg} \text { bwt }\end{array}$ & 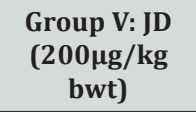 \\
\hline \multicolumn{6}{|l|}{ Cell-mediated immune response } \\
\hline DTH response & $15.6 \pm 2.12$ & $27.63 \pm 3.58$ & $40.21 \pm 5.57^{*}$ & $48.13 \pm 9.19^{* *}$ & $44.61 \pm 13.04^{* *}$ \\
\hline \multicolumn{6}{|l|}{ Lymphocyte proliferation } \\
\hline Un-stimulated & $0.395 \pm 0.012$ & $0.415 \pm 0.010$ & $0.419 \pm 0.008$ & $0.422 \pm 0.009$ & $0.415 \pm 0.009$ \\
\hline OVA stimulated & $0.617 \pm 0.006$ & $0.658 \pm 0.010$ & $0.662 \pm 0.009^{*}$ & $0.661 \pm 0.012^{*}$ & $0.641 \pm 0.011$ \\
\hline Mitogen Con-A stimulated & $0.817 \pm 0.026$ & $0.900 \pm 0.006^{* *}$ & $0.914 \pm 0.006^{* *}$ & $0.996 \pm 0.008^{* *}$ & $0.907 \pm 0.010^{* *}$ \\
\hline
\end{tabular}

Animals were sacrificed $24 \mathrm{~h}$ after the administration of $\mathrm{CJ}$ for 10 days at different concentration. DTH is expressed as footpad thickness (in $\mathrm{mm}) 24 \mathrm{~h}$ after being challenged with $\mathrm{g}$ RBC. Lymphocyte proliferation is expressed as absorbance measured at 570 by un-stimulated, OVA stimulated and mitogen Con-A stimulated spleen cells. Data represent mean \pm S.E. $(n=5)$.

${ }^{*} p<0.05,{ }^{* *} p<0.01$, when compared to control.

\section{Effect of CJ Lymphocyte Proliferation Assay}

No significant proliferation was observed in un-stimulated splenocytes isolated from CJ treated mice while significantly enhanced splenocyte proliferation was observed when stimulated with antigen OVA and mitogen Con A (Table 1). Significant sple-

\section{Effect Of Cjon Th1 (Il-2/Ifn-Г) And Th2 (Il-4/Il-10) Cytokines}

nocyte proliferation was observed at 75 and $100(p<0.05) \mu \mathrm{g} /$ $\mathrm{kg}$ body weight upon OVA stimulation as compared with control. The maximum increase in lymphocyte proliferation was observed at $100 \mu \mathrm{g} / \mathrm{kg}$ body weight $(p<0.01)$ in Con A-stimulated group (Table 1).

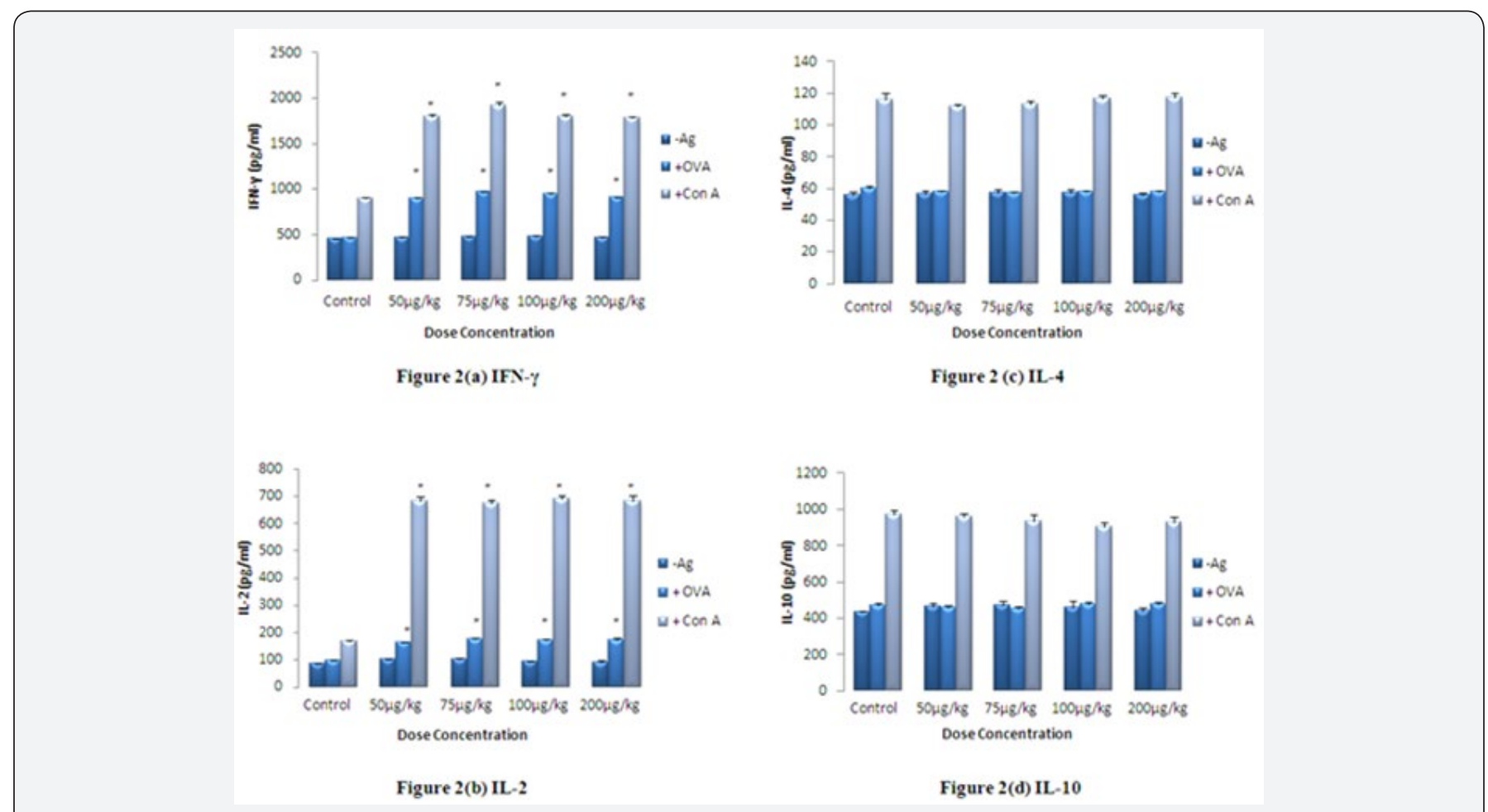

Figure 2 (a-d): CJ onTh1 (IL-2/IFN- $\mathrm{y}$ ) and Th2 (IL-4/IL-10) cytokine profiles of mice immunized with OVA. 
Lymphocytes were isolated from spleen of different test groups of mice given CJ orally. Splenocytes $\left(2 \times 10^{5}\right.$ cells/well) were stimulated with Con $A(2 \mu \mathrm{g} / \mathrm{ml})$ and OVA $(5 \mu \mathrm{g} / \mathrm{ml})$ for $72 \mathrm{~h}$ and the production of Th1 and Th2 cytokines in the cultured supernatant was measured according to the instruction given by the manufacturer of ELISA cytokine kit. The values are presented as mean \pm S.E. $(n=5)$ and significant differences were designated $\mathrm{as}^{*} p<0.01$ when compared to the respective control.

The level of Th1 (IL-2/IFN- $\gamma$ ) cytokines was significantly higher $(p<0.01)$ at all doses in the culture supernatant of OVA and Con-A stimulated splenocytes isolated from mice treated with different doses of $\mathrm{CJ}$ as compared to control (Figures 2a \& 2b). No significant change was observed in the level of Th2 (IL4/IL-10) cytokines suggesting the Th1 directing response of CJ. Maximum increase in the level of Th1 cytokines was observed at $75 \mu \mathrm{g} / \mathrm{kg}$ body weight $(p<0.01)$ (Figure $2 \mathrm{a} \& 2 \mathrm{~b}$ ). There was no significant change in the level of IL-1 $\beta$, while the level of TNF- $\alpha$ increased significantly in spleen cell culture isolated from CJ treated group when compared with respective control (Figures 3a \& 3b). The maximum enhancement in the level of TNF- $\alpha$ was observed at $100 \mu \mathrm{g} / \mathrm{kg}$ body weight group.

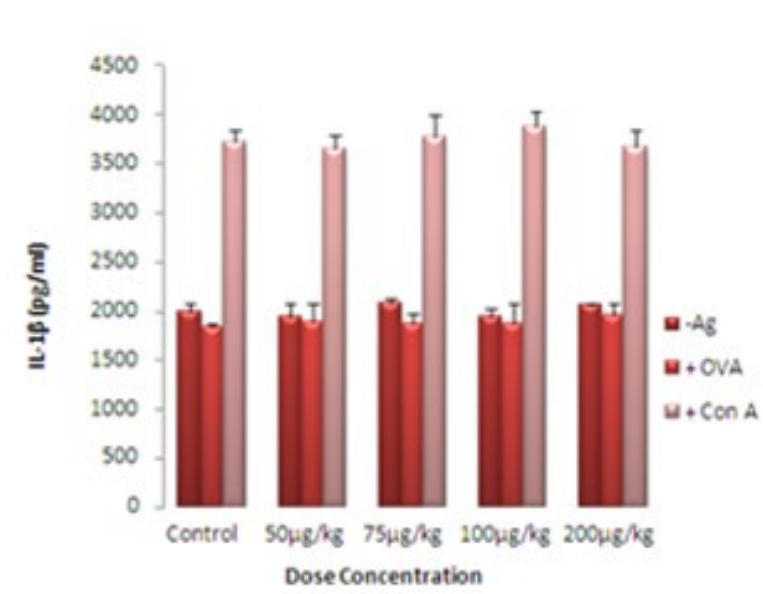

Figure 3 (a) IL-1ß

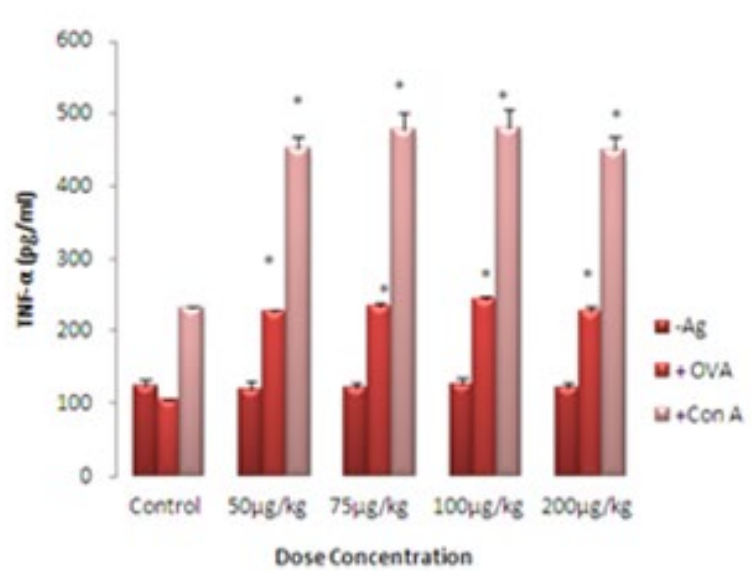

Figure 3 (b) TNF- $a$

Figure $3(a, b)$ : Effect of CJ on inflammatory cytokine (TNF- $\alpha /$ IL-1 $1 \beta)$ profiles of mice immunized with OVA.

Lymphocytes were isolated from spleen of different test groups of mice given CJ nanoparticles orally. Splenocytes $\left(2 \times 10^{5}\right.$ cells/well) were stimulated withCon $\mathrm{A}(2 \mu \mathrm{g} / \mathrm{ml})$ and OVA $(5 \mu \mathrm{g} / \mathrm{ml})$ for $72 \mathrm{~h}$ and production of inflammatory cytokines in the cultured supernatant was measured according to the instruction given by the manufacturer of ELISA cytokine kit. The values are presented as mean \pm S.E. $(n=5)$ and significant differences weredesignated $a^{*} p<0.01$ when compared to the respective control.

\section{Discussion}

Calcined Jade used in the preparation of many traditional medicines that has been hypothesized to contain nano particles to boost biological impact. However, to date, there has been little experimental validation carried out to confirm this hypothesis .In the present study, we evaluated the effect of oral exposure of CJ on the cell mediated immune response in Swiss albino mice. As shown here, oral administration of $\mathrm{CJ}$ likely led to significant increase in Th1 directing cell mediated immunity in the exposed hosts.

Infectious agents can lead to severe pathology in both humans and animals, and immunity to infection relies on the development of a strong cell-mediated immune response [12]. The effective immune response is mediated by CD4+ and CD8+ T cells and is associated with the production different cytokines [13]. Cell mediated immunity, mediated by T lymphocytes, are crucial for combating with intracellular infection. When T cells interact with the antigen present on antigen presenting cells, they are converted into lymphoblast and start producing lymphokines. Lymphokines attract more scavenger cells to the site of antigen interaction and promote defensive action to shadowing and eventually eliminating the antigenic molecule [14]. In this study, upon challenging the mice with the g RBCs, footpad thickness was significantly enhanced in $\mathrm{CJ}$ treated mice suggesting cell mediated immune enhancement.

Effective T cell immunity is also exhibited by the induction of significantly enhanced OVA/Con A-stimulated lymphocyte proliferation in $\mathrm{CJ}$ treated mice .Co-stimulatory signal, a secondary signal plays a critical role for the determination of specific immune response which is mediated by co-stimulatory molecules present on APCs. The immune response is maintained by CD-80 co-stimulatory molecule while the immune memory function is maintained by CD-86 co-stimulatory molecule [15]. Also, the role of CD-86 is important in the proliferation of Th2 lymphocytes and their cytokines like IL-4, IL-5 and IL-10 secre- 
tion $[16,17]$, whereas proliferation of Th1 lymphocytes and their cytokines like IL-2, IFN- $\gamma$ and TNF- $\alpha$ production depends on the induction of CD80 [18,19]. CJ increased the expression of CD-80 while CD-86 decreased, suggesting that $\mathrm{CJ}$ may have the capacity to enhance the Th1 immunity and may not alter the Th-2 immune response.

Cytokines like IL-2, IFN- $\gamma$ and TNF- $\alpha$ secreted by Th1 lymphocytes induces other effecter immune cells to eliminate the intracellular antigen [20]. Analysis of these cytokines exhibited that the production of Th1 (IL-2/IFN- $\gamma$ ) cytokines was significantly higher in CJ treated mice while the level of Th2 (IL-4/ IL-10) cytokines showed no effect in OVA-immunized mice. A non-significant increase in the level of inflammatory cytokine (IL-1 $\beta$ ) indicate that CJ may not stimulate chronic inflammatory response, while significant increase in the level of TNF- $\alpha$ suggests that $\mathrm{CJ}$ might enhance the Th-1 directing response, as TNF- $\alpha$ along with IFN- $\gamma$ and IL- 2 skews the response in favor of Th-1 immunity [21]. As immunochemical analysis shown increase Th1 (IL-2/IFN- $\gamma$ ) cytokines which indicate that CJ can up-regulate Th- 1 type of immunity.

\section{Conclusion}

In conclusion, traditional medicinal materials have been used for thousands of years and are believed to be abundant, safe, and inexpensive. Although the protection against many infections is highly dependent on the presence of a Th1-type immune response, however, the use of recombinant immunotherapy is limited by the toxicity associated with higher doses. In comparison with the use of recombinant immunotherapy, CJ may be safe and easy for human use. Our data suggest that $\mathrm{CJ}$ contain potent immune stimulants which may provide the rational basis for their therapeutic use as biological response modifiers. Therefore, this potent mineral alone or in the form of formulations should be further evaluated for use in animal and clinical trials. In future experiments it would be helpful to confirm the efficacy of vaccine immunization and the adjuvant properties of CJ.

\section{Conflict of Interest}

The authors report no competing financial interestand are responsible for the content and writing of the paper, which is the explicit work of authors under the overall supervision of FK.

\section{Acknowledgment}

The Indian Council of Medical Research (ICMR) is acknowledged for financial assistance for this study.

\section{References}

1. Hartwig A, Asmuss M, Blessing H, Hoffmann S, Jahnke G, et al. (2002) Interference by toxic metal ions with zinc-dependent proteins involved in maintaining genomic stability. Food Chem Toxicol 40(8): 1179-1184.

2. Kean WF, Hart L, Buchanan WW (1997) Auranofin. Brit J Rheumatol 82: 560 .
3. Said HM (1997) Hamdard pharmacopoeia of eastern medicine. Sri satguru publication, India.

4. Tariq M, Chaudhary SS, Imtiyaz S (2013) Introduction to kushta: A herbomineral Unani formulation. J Pharmaceutical and Scientific Innovation 2(1): 14-17.

5. Singh SK , Gautam DNS, Kumar M, Rai SB (2010) Synthesis, characterization and histopathological study of a lead based Indian traditional drug Naga Bhasma. Indian journal of Pharmaceutical Science 72(1): 24-30.

6. Bhowmick TK, Suresh AK, Kane SG, Joshi AC, Bellare JR (2009) Physicochemical characterization of an Indian traditional medicine, JasadaBhasma. Detection of nanoparticles containing non stoichiometric zinc oxide. J Nanoparticle Res 11: 655-664.

7. Wadekar MP, Rodeb CV, Bendale YN, Patil KR, Prabhune AA (2005) Preparation and characterization of a copper based Indian traditional drug: TamraBhasma. J. Pharmaceutical and Bio-medical Analysis 39(5): 951-955

8. The Wealth of India: A dictionary of Indian raw materials and industrial products (1996) Raw material series, publication and information directorate, CSIR, New Delhi, pp. 202-207.

9. Gupta A, Khajuria A, Singh J, Singh S, Suri KA, et al. (2011) Immunological adjuvant effect of Boswelliaserrata (BOS 2000) on specific antibody and cellular response to ovalbumin in mice. IntImmunopharmacol 11(8): 968-975

10. Bashir S, Ali S, Khan F (2015) Partial Reversal of Obesity-Induced Insulin Resistance Owing to Anti-Inflammatory Immunomodulatory Potential of Flaxseed Oil. Immunological Investigations 44(5): 451-469

11. Ahmad W, Jantan I, Kumolosasi E, Bukhari SNA (2015) Immunostimulatory effects of the standardized extract of Tinosporacrispaon innate immune responses in Wistar Kyoto rats. Drug Design Development and Therapy 9: 2961-2973

12. Denkers EY, Gazzinelli RT (1998) Regulation and function of T-cellmediated immunityduring Toxoplasma gondii infection. ClinMicrob Rev 11: 569-588

13. Gazzinelli RT, Hakim FT, Hieny S, Shearer GM, Sher A (1991) Synergistic role of $\mathrm{CD}^{+}$and $\mathrm{CD}^{+} \mathrm{T}$ lymphocytes in IFN-gamma production and protective immunity induced by an attenuated Toxoplasma gondii vaccine. J Immunol146(1): 286-292

14. Najjar I, Fagard R (2010) STAT1 and pathogens, not a friendly relationship. Biochimie 92(5): 425-444

15. Lord GM, Matarese G, Howard JK, Baker RJ, Bloom SR, et al. (1998) Leptin modulates the T-cell immune response and reverses starvationinduced immunosuppression. Nature 394(6696): 897-901

16. Girvin AM, Dal Canto MC, Rhee L, Salomon B, Sharpe A, et al. (2000) Critical role for B7/CD28 costimulation in experimental autoimmune encephalomyelitis a comparative study using costimulatory moleculedeficient mice and monoclonal antibody blockade. J Immunol 164(1): 136-143.

17. Hofer ME, Jirapongsanuruk O, Trumble AE, Leung DYM (1998) Upregulation of B7.2, but not B7.1, on B cells from patients with allergic asthma. J. Allergy Clin Immunol 101(1pt1): 96-102.

18. Jaffar ZH, Stanciu L, Pandit A, Lordan J, Holgate ST, et al. (1999) Essential role for both CD80 and CD86 costimulation, but not CD40 interactions, in allergen-induced Th2 cytokines production Th2 cytokine production from asthmatic bronchial tissue: role for $\alpha \beta$ but not $\gamma \delta$, T cells. J Immunol 163(11): 6283-6291.

19. Bashian GG, Braun CM, Huang SK, Kagey-Sobotka A, Lichtenstein LM, et al. (1997) Differential regulation of human antigen-specific Th1 and 
Th2 responses by the B-7 homologues, CD80 and CD86. Am J Respir Cell Mol Biol 17(2): 235-242.

20. Sun Y 2008, Liu J (2008) Adjuvant effect of water-soluble polysaccharide (PAP) from the mycelium of Polyporusalbicans on the immune responses to ovalbumin in mice. Vaccine 26(31): 3932-3936.
21. Sen P 1992, Mendiratta PK, Ray A (1992) Effects of Azadirachtaindicaon some biochemical, immunological and visceral parametersin normal and stressed rats. Indian J Exp Bio 30(12): 70-175.

\section{Your next submission with Juniper Publishers} will reach you the below assets

- Quality Editorial service

- Swift Peer Review

- Reprints availability

- E-prints Service

- Manuscript Podcast for convenient understanding

- Global attainment for your research

- Manuscript accessibility in different formats (Pdf, E-pub, Full Text, Audio)

- Unceasing customer service

Track the below URL for one-step submission https://juniperpublishers.com/online-submission.php 